\title{
Studying and modeling the air pollution caused by chemical pollutants emitting from thermal power station and generators in Baghdad city
}

\author{
Nagam Obaid Kariem \\ Iraq-Baghdad, Bab-AL-Muthem, Al-Mustansiryiah University, College of Engineering-Environmental \\ Engineering
}

Rec. 6 Jun, 2012 Accpt. 2 Aug, 2012

\begin{abstract}
This work refers to study and calculate the concentrations of pollutants that emitted to air of the Baghdad city through the production of electrical power by electrical generator and small generators. The electrical power plant in Baghdad (area of study) consumed a large amount fuel for producing the electricity because of large number of people that living in this city. Fixed box model was used to explain the distribution of concentrations of pollutants and the rates of emissions of pollutants from the city. The pollutants that included in this study were carbon monoxide $(\mathrm{CO})$, sulfur dioxide $\left(\mathrm{SO}_{2}\right)$, nitrogen oxides (NOX), hydrocarbons, and particulates. The results showed a high accuracy (low error) between the measured concentrations by portable measuring device and the calculated concentrations by the Fixed box model for all pollutants. The average error up to $8 \%, 9 \%, 6 \%$, and $5 \%$ for carbon monoxide, sulpher dioxide, nitrogen oxides, and particulates, respectively. The results showed that when the average velocities increased the pollutants concentrations decreased. The major source of HC was the electrical power plant for Ministry of Electricity by about $80 \%$ from the total pollutants that used different types of fuel, followed by Generator of state of Government and Emergency generator, then Mini-emergency generator.
\end{abstract}

Key words: Air pollution, carbon monoxide, sulfur dioxide, nitrogen oxides, HC, particulates, and fixed box model.

\section{Introduction}

Air pollution affects our atmosphere and can endanger human health and welfare of plants and animals. Ozone depletion caused by air pollution has been a big concern, especially for health reasons. The primary air pollutants are carbon dioxide $\left(\mathrm{CO}_{2}\right)$, sulfur dioxide $\left(\mathrm{SO}_{2}\right)$, nitrogen monoxide (NO), and nitrogen dioxide $\left(\mathrm{NO}_{2}\right)$. Carbon monoxide and sulfur dioxide are emitted through combustion. A number of concerns related to air pollutants include acid rain, global warming, particulates, haze, smoke, and Asbestos (Miller 1996; Smith 1991).

The main sources of these primary air pollutants are human activity (anthropogenic sources) and natural sources. Natural sources that cause air pollution are minor, it includes the fire (which causes the release of carbon monoxide and smoke), dust, volcanic activity, pine trees, and methane emitted from animals' digestion (Opris et al., 1993; Anderson et al., 1998).

Air pollution includes emissions from automobiles, burning of fossil fuels, power plants, burning of wood and fireplaces, chemicals, fume from paint and aerosol, military uses and waste deposits(5). Thermal power plants are major sources of particulates, SO2 and NOx. Depending upon the type of fuel used emission of one or more of these pollutants may be of environmental significance. A large amount of particulates as fly ash is emitted from coal fired plants, particularly if the ash content of coal is high and a fly ash removal unit, such as, an electrostatic precipitation (ESP) is not used (Ariana et al., 2007; EPA,1976).

The World Health Organization estimates that 4.6 million people die each year from causes directly attributable to air pollution" Air pollution links to asthma, bronchitis, emphysema, lung and heart diseases, and respiratory allergies due to mainly indoor air pollution (Barrie 2001; EPA, 1976).

Air pollution models are classified according to type, downwind distance, and mathematical approach. The mathematical approach divided into many types which are statistical models, direct numerical solution.

$\begin{array}{ll}\text { * Corresponding author: } & 23 \\ \text { Dr. Nagam Obaid Kariem } & \\ 凶 \text { nagam75@yahoo.com } & \end{array}$


The objective of the present work is to simulate the air pollution caused by $(\mathrm{CO}$, $\mathrm{NOx}, \mathrm{SO}_{2}, \mathrm{HC}$, and particulates) using the box model which assume that pollutant concentrations are uniform throughout a prescribed region (its suitable if the source of pollutants was area source like in Baghdad were the power plant generators and emergency generators distributed over the whole area of city' (Barrie, 2001).

Giannouli et al., (2006), E.E.A (2005) and C.S.T (2004) defined Sulfur dioxide $\left(\mathrm{SO}_{2}\right)$, as a colorless compound, but has a suffocating, pungent odor. The primary source of $\mathrm{SO}_{2}$ is the combustion of sulfurcontaining fuels (e.g., oil and coal). Exposure to $\mathrm{SO}_{2}$ can cause the irritation of lung tissues and can damage health and materials.

Nitrogen oxides (NO and NO2), the $\mathrm{NO} 2$ is a reddish-brown gas with a sharp odor. The primary source of this gas is vehicle traffic, and it plays a role in the formation of tropospheric ozone. Large concentrations can reduce visibility and increase the risk of acute and chronic respiratory disease (Hertel et al., 1996; Giannouli et al., 2006).

Paul G. (1995) cited that carbon monoxide (CO). This odorless, colorless gas is formed from the incomplete combustion of fuels. Thus, the largest source of $\mathrm{CO}$ today is motor vehicles and power stations. Inhalation of $\mathrm{CO}$ reduces the amount of oxygen in the bloodstream, and high concentrations can lead to headaches, dizziness, unconsciousness, and death

\section{Modeling and area of study:}

The box model in this research consider the area that pollutants emitted form them take the shape of rectangular city as shown in figure (1). To compute the air pollutant concentration a material balance was made according to equation (1) in this city on each pollutant.

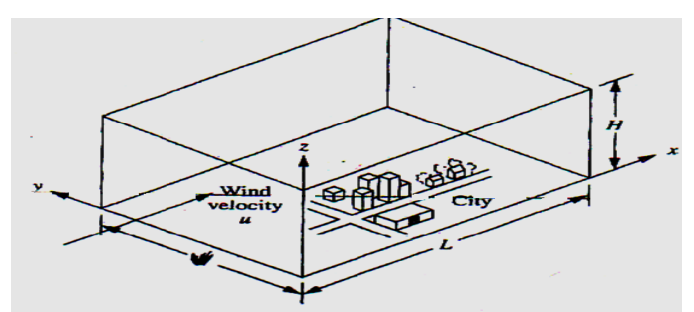

Figure (1): Rectangular city, showing meaning of symbols used in Box model.

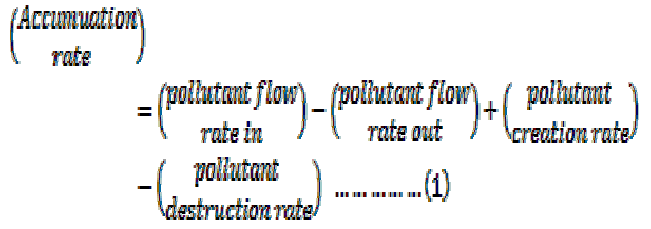

The assumption for model in this research was

1. The city was rectangle with dimensions $W$ and $L$ and one of the side parallel to the wind direction.

2. Atmospheric turbulence produced complete mixing of pollutants up to height $H$ and no mixing above this height.

3. The pollutants concentration was uniform in the whole volume of air over the city.

4. The velocity was independent of time.

5. The concentration of each pollutant in the air entering the city (at $x=0$ ) was constant and equal to $b$ $\left(\operatorname{microgram} / \mathrm{m}^{3}\right)$.

6. The air pollutant emission rate of the Baghdad city is $Q$.This was normally given as an emission rate per unit area $q\left(\mathrm{~g} / \mathrm{s} \cdot \mathrm{m}^{2}\right)$. one could convert to other by using equation (2).

$$
Q=q \cdot A_{B}
$$

\section{Wher $A_{B}$ was the area of the baghdad city}

7. There are no pollutant leaves or enters through the top of the box, or through the sides that are parallel to the wind direction.

8. The accumulation rate equal zero (no change with time), and the destruction rate equal zero.

Let $\mathrm{C}_{\mathrm{B}}$ equal the concentration of pollutant in the Baghdad city

The rate of pollutant in $=\mathrm{uHWb}$

The rate of pollutant out $=\mathrm{uHWC}_{\mathrm{B}}$ (4)

By substituted eq. (2), eq. (3), and eq. (4) in eq. (1) and using the assumptions above we get

$u H W b-u H W c_{B}+q W L-0=0 \ldots \ldots(5)$ 
By re-arranging eq. (5), we get eq. (6)

$$
C_{B}=b+\frac{q L}{u H} \ldots \ldots(6)
$$

Equation(6) was used for each chemical pollutants as showing in equations listing from eq.(7) to eq.(11).

$$
\mathrm{C}_{\mathrm{SO} 2}=\mathrm{b}_{\mathrm{SO} 2}+\left(\left(\mathrm{q}_{\mathrm{SO} 2} \mathrm{~L}\right) /(\mathrm{uH})\right)
$$

$\mathrm{C}_{\text {particulates }}=\mathrm{b}_{\text {particulates }}+(\mathrm{q}$ particulates $* \mathrm{~L}) /$

$$
\left.\left(\mathrm{u}^{*} \mathrm{H}\right)\right)
$$

$$
\mathrm{C}_{\mathrm{NOX}}=\mathrm{b}_{\mathrm{NOX}}+\left(\left(\mathrm{q}_{\mathrm{NOX}} \mathrm{L}\right) /(\mathrm{uH})\right)
$$

$\mathrm{C}_{\mathrm{CO}}=\mathrm{b}_{\mathrm{CO}}+\left(\left(\mathrm{q}_{\mathrm{CO}} \mathrm{L}\right) /(\mathrm{uH})\right.$

In figure (2) all symbols in Box model were fixed on a map of Baghdad city .The map of baghdad in figure (2) got from the program called google earth.

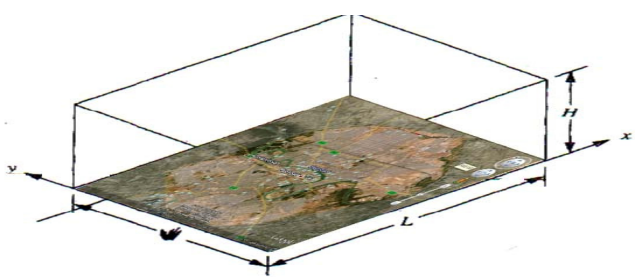

Figure (2): symbols of box model fixed on the baghdad city

\section{Experimental work and calculation}

Table (1) represent the amount of consumed fuel for generating electrical power for baghadad city by $\mathrm{m}^{3} / \mathrm{day}$, this information taken from ministry of

\begin{tabular}{|c|c|c|c|c|}
\hline No. & Fuel & Type of power plant & Fuel(m³/day) & Fuel (ton/year) \\
\hline 1 & Heavy oil ${ }_{1}$ & $\begin{array}{l}\text { Electrical power Plant for } \\
\text { ministry of electricity }\end{array}$ & 3025 & 963901.124 \\
\hline 2 & Heavy oil ${ }_{2}$ & $\begin{array}{l}\text { Electrical power Plant for } \\
\text { ministry of electricity }\end{array}$ & 15155 & 542094.5 \\
\hline 3 & Light oil $_{1}$ & $\begin{array}{l}\text { Electrical power Plant for } \\
\text { ministry of electricity }\end{array}$ & 748 & 141970.4 \\
\hline 4 & Light oil $_{2}$ & $\begin{array}{l}\text { Electrical power Plant for } \\
\text { ministry of electricity }\end{array}$ & 1400 & 434350 \\
\hline 5 & Light oil $_{3}$ & $\begin{array}{l}\text { Generator of state of government } \\
\text { and emergency generator }\end{array}$ & 1400 & 353685 \\
\hline 6 & ${\text { Light } \text { oil }_{4}}$ & Mini-emergency generator & 950 & 266996.5 \\
\hline
\end{tabular}
electricity and ministry of oil in iraq, the anthor inforamtion about fuel was the density as shown below.

Table (1): Data of the amount of concumed fuel for electrical power polant in Baghdad city.

From table (1), the annual amount consumption in the last column in the table for each type of fuel by mathematics could be estimated, for example, fuel type one (in row one) calculating by multiplying density $\left(873 \mathrm{~kg} / \mathrm{m}^{3}\right)$ of the fuel by the daily consumption, then deviding the results on 365 day, the results devided on 1000 to convert from $\mathrm{kg}$ to ton .

From the map of baghdad according to google earth program indicated that the length and width of the stusy area was determined $($ length $(\mathrm{L})=41234 \mathrm{~m}$ and width $(\mathrm{W})=27495 \mathrm{~m})$, so according to this dimensions the area of stydy equal to $1134000000 \mathrm{~m}^{2}$.

The measurment of concentrations in table (2), was measured by air pollutant device called Lacom (portable flue gas monitoring), The Lancom 4 is the most accurate, robust and flexible portable flue gas analyzer currently available. The measurements specification of this device can be seen in table (3). The shape of the portable flue gas monitoring was included in figure (3). The portable gas analyzer had a sample probes (with length $3 \mathrm{~m}$, hose $10 \mathrm{~m}, \quad 600 \mathrm{C}^{\circ}$ maximum flue gas temperature) were indicated in figure (4).

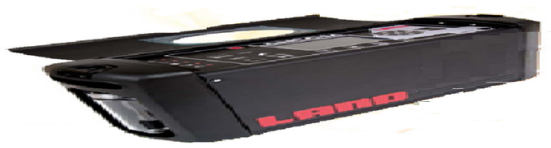

Figure (3): The shape of the portable flue gas monitoring.

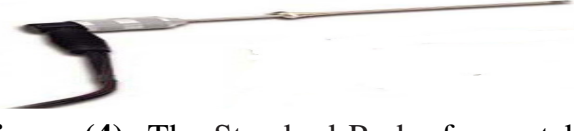

Figure (4): The Standard Probe for portable gas monitoring.

\section{Results and discussion:}

The average pollutants concentartions at the upwind stream of baghadad (before 
entring Baghadad city) were measured. The device measuring the concentration of carbon monoxide $\mathrm{CO}$, nitrogen oxides $\mathrm{SOx}$, sulfur dioxide $\mathrm{SO}_{2}$, and particulate matter.
Table (2) show the concentration of pollutants at different time of year.

\begin{tabular}{|c|c|c|c|c|c|}
\hline \multicolumn{7}{|c|}{ Poluutants concentrations $\left(\boldsymbol{\mu g} / \mathbf{m}^{3}\right)$} & $\begin{array}{c}\text { Average } \\
\text { Velocity } \\
(\mathbf{m} / \mathbf{s})\end{array}$ \\
\hline Date of Tests & $\mathbf{C O}_{\mathbf{2}}$ & $\mathbf{S O}_{\mathbf{2}}$ & $\mathbf{N O}_{\mathbf{x}}$ & Particulates & 2.5 \\
\hline January & 0.38 & 0.15 & 0.033 & 5.0 & 2.8 \\
\hline February & 0.33 & 0.14 & 0.038 & 5.3 & 3.2 \\
\hline March & 0.51 & 0.16 & 0.033 & 5.2 & 3.2 \\
\hline April & 0.419 & 0.17 & 0.035 & 5.4 & 3.3 \\
\hline May & 0.62 & 0.15 & 0.038 & 5.5 & 3.9 \\
\hline June & 0.50 & 0.16 & 0.031 & 5.0 & 4.1 \\
\hline July & 0.52 & 0.17 & 0.033 & 5.2 & 3.6 \\
\hline August & 0.51 & 0.17 & 0.034 & 5.3 & 2.8 \\
\hline September & 0.49 & 0.15 & 0.039 & 5.1 & 2.5 \\
\hline October & 0.48 & 0.16 & 0.032 & 5.2 & 2.5 \\
\hline November & 0.58 & 0.16 & 0.034 & 6.1 & 2.4 \\
\hline December & 0.44 & 0.14 & 0.037 & 6.2 & \\
\hline
\end{tabular}

Table (2): The average measured concentrations of gases (before entring Baghadad city).

\begin{tabular}{|c|c|c|c|}
\hline No. & sensor & Range(ppm) & Accuracy \% of range \\
\hline 1 & CO & 0 to 6000 & $\pm 1 \%$ \\
\hline 2 & NO $_{\mathbf{x}}$ & 0 to 5000 & $\pm 2 \%$ \\
\hline 3 & $\mathbf{S O}_{\mathbf{2}}$ & 0 to 4000 & $\pm 2 \%$ \\
\hline
\end{tabular}

Table (3): Portable gas specification

Figure (5), shows that the high percentage of particulate matter emitting from Baghdad city was from the heavy oil (fuel oil) and this percentage reach to about $87 \%$ from the total amount of particulate emitting from this city. This is because Fuel oil was made of long hydrocarbon chains, particularly alkanes, cycloalkanes and aromatics. From these results and the other data related with Baghdad city in the fixed box model, we could estimate the total amounts of pollutants emitted from Baghdad city.

The results show also that the major source of emitting pollutant was the electrical power plant for Ministry of Electricity that used the heavy fuel oil, followed by Mini-emergency generator that used light oil (Gasoline), then followed by Diesel that used for producing electric power (that used in electrical plant for ministry and in generator of state of government and emergency generator).

The small amounts of emitting particulates was from Light oil (Dry gas), therefore, dry gas can be called the clean fuel, and this amount just to about 55.37 Ton/year.

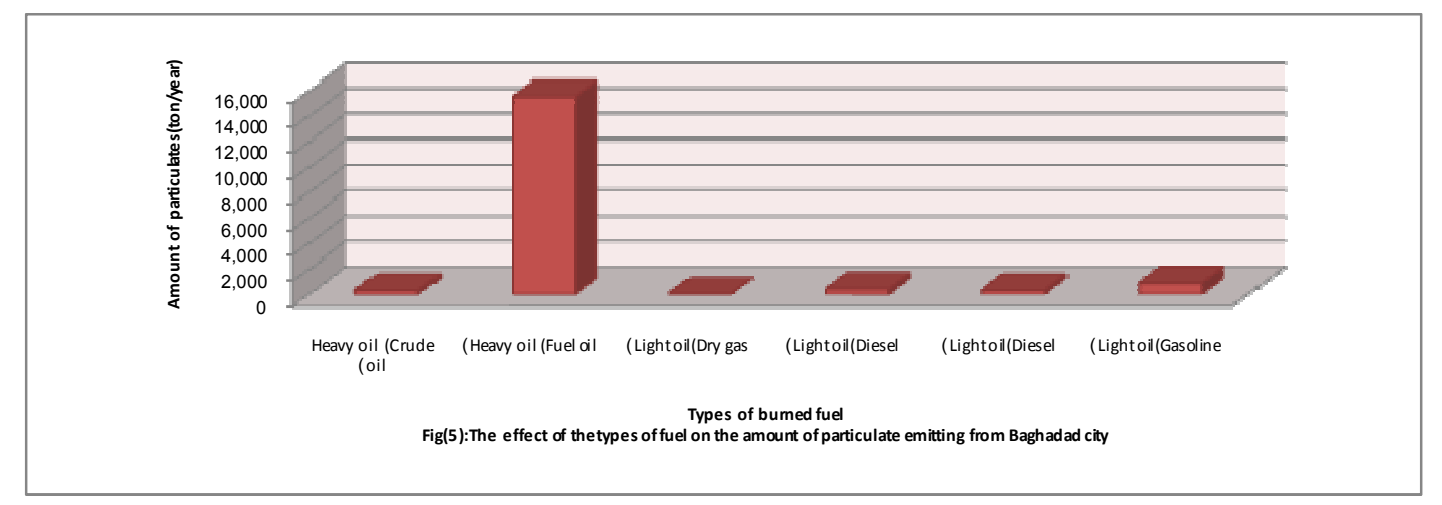

Figure(6) and (7) show that the major source of sulpher dioxide and $\mathrm{HC}$ was the electrical power plant for Ministry of Electricity, where it uses different types of 
fuel, followed by Generator of state of government and emergency generator, then followed Mini-emergency generator.

The results showed that the fuel type - dry gas (light oil) gives the small amounts of Sulpher dioxide by about less than 1 percent of the total amounts of pollutant $\left(\mathrm{SO}_{2}\right)$ that emitting to the air and less than 2 percent for the total amounts of pollutant HC. That emitting to the air.

Figure (8), showed that the high percentage of carbon monoxide emitting from Baghdad city was from the heavy oil (fuel oil) and this percentage reach to about $55 \%$ from the total amount of carbon monoxide emitting from this city, this is because Fuel oil contain a large amounts of carbon.
In table(4) indicated that the average concentrations of gases measuring and calculating by the Box model, it gave considerable results in comparison with those measured by portable measuring device. The average error up to $8 \%, 9 \%, 6 \%$, and $5 \%$ for carbon monoxide, sulpher dioxide, nitrogen oxides, and particulates respectively. The results in this table shows that when the average velocities increased the pollutant concentrations decreased, this was occurred because the dispersion of pollutants increased with increase of velocity.

The results in table (3) showed that amount of pollutants emission from Baghdad city were not changes with the times of year.
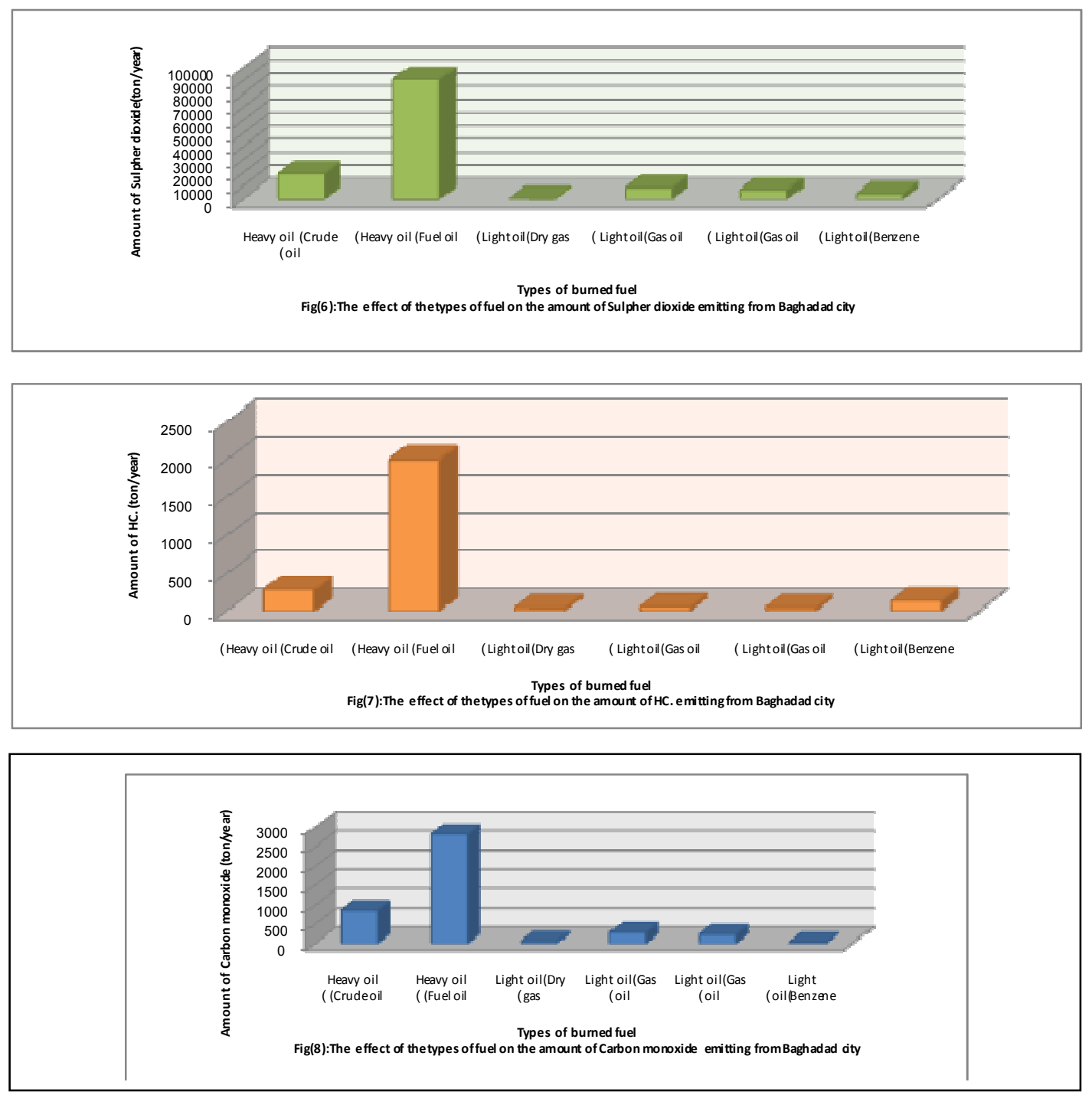


\begin{tabular}{|c|c|c|c|c|c|c|c|c|c|}
\hline \multicolumn{10}{|c|}{ Pollutans concenration $\left(\boldsymbol{\mu g} / \mathbf{m}^{\mathbf{3}}\right)$} \\
\hline $\begin{array}{c}\text { Data of } \\
\text { test }\end{array}$ & $\begin{array}{c}\mathbf{C O}_{\mathbf{2}} \\
\text { Mea. }\end{array}$ & $\begin{array}{c}\mathbf{C O}_{\mathbf{2}} \\
\text { Cal. }\end{array}$ & $\begin{array}{c}\text { SO2 } \\
\text { Mea. }\end{array}$ & $\begin{array}{c}\text { SO2 } \\
\text { Cal. }\end{array}$ & $\begin{array}{c}\text { NOx } \\
\text { Mea. }\end{array}$ & $\begin{array}{c}\text { NOx } \\
\text { Cal. }\end{array}$ & $\begin{array}{c}\text { Particulates } \\
\text { Mea. }\end{array}$ & $\begin{array}{c}\text { Particulates } \\
\text { Cal. }\end{array}$ & $\begin{array}{c}\text { Average } \\
\text { velociy } \\
(\mathbf{m} / \mathbf{s})\end{array}$ \\
\hline January & 2.2 & 2.1 & 17 & 18.2 & 40 & 44.1 & 8 & 8.1 & 2.5 \\
\hline Febraury & 1.9 & 1.8 & 17 & 16.1 & 36 & 39.5 & 7.6 & 8.1 & 2.8 \\
\hline March & 1.8 & 1.9 & 11 & 14.1 & 35 & 34.6 & 7.1 & 7.6 & 3.2 \\
\hline April & 1.7 & 1.8 & 13 & 14 & 31 & 34.6 & 8.3 & 7.8 & 3.2 \\
\hline May & 2 & 1.9 & 18 & 18.9 & 28 & 33.6 & 7.7 & 7.8 & 3.3 \\
\hline June & 1.1 & 1.6 & 12 & 11.5 & 29 & 28.4 & 6.8 & 7.1 & 3.9 \\
\hline July & 1.6 & 1.6 & 10 & 11 & 23 & 26.9 & 6 & 7 & 4.1 \\
\hline August & 1.5 & 1.7 & 13 & 12.5 & 28 & 30.8 & 7.6 & 7.5 & 3.6 \\
\hline September & 1.8 & 2 & 14 & 16.1 & 30 & 39.5 & 7.6 & 7.9 & 2.8 \\
\hline October & 2 & 2.2 & 18 & 17.9 & 43 & 44.2 & 8.3 & 8.3 & 2.5 \\
\hline November & 2.1 & 2.3 & 16 & 17.9 & 40 & 44.2 & 8.1 & 9.3 & 2.5 \\
\hline December & 2.3 & 2.2 & 18 & 18.7 & 47 & 46.2 & 8.2 & 9.4 & 2.4 \\
\hline
\end{tabular}

Table(4): The average concentrations of gases measuring and calculated by Box Model (Baghadad city).

\section{Symbols:}

$\mathrm{A}_{\mathrm{B}}$ Area of the baghdad city $\left(\mathrm{m}^{2}\right)$.

$b$ Concentration of each pollutant in the air entering the city $\left(\right.$ microgram $\left./ \mathrm{m}^{3}\right)$.

$\mathrm{C}_{\mathrm{B}}$ Concentration of pollutant in the Baghdad city (microgram $\left./ \mathrm{m}^{3}\right)$.

$\mathrm{H}$ High of the space over the city where the concentration of pollutants are uniform $(\mathrm{m} / \mathrm{s})$.

L Length of Baghdad city (m).

Q Emission rate.

q Emission rate per unit area $\left(\mathrm{g} / \mathrm{s} . \mathrm{m}^{2}\right)$.

u Average velocity of $\operatorname{air}(\mathrm{m} / \mathrm{s})$.

W Width of Baghdad city (m).

\section{References:}

Miller, C.A. (1996). Hazardous Air Pollutants from the Combustion of an Emulsified Heavy Oil in a Fire tube Boiler. EPA-600/R-96-019. U.S. Environmental Protection Agency.

Smith, (1991). Development of Particulate Emission Factors For Wet Cooling Towers EPA No.68-D0-0137

Opris, C.N., Gratz, L.D., Bagley, S.T., Baumgard, K.J., Leddy, D.G. and Johnson, J.H. (1993). The Effects of Fuel Sulfur Concentration on Regulated and Unregulated HeavyDuty Diesel Emissions.SAE Technical Paper 930730.

Anderson, M.H. and Skelley, A.P. (1998). A low temperature oxidation system for the control of NOx emissions using ozone injection. Institute of Clean Air Companies, Forum '98, Durham, NC.

EPA (1976). Air Pollution Emission Test, ESB Canada Limited, Mississouga, Ontario, EMB-76-BAT-3,U. S. Environmental Protection Agency, Research Triangle Park, NC, August 1976.

Ariana, I.M., Nishida, O., Fujita, H., Harano, W. and Fujio, M. (2007). Development of Electrostatic Precipitator to Reduce Marine Diesel Particulate Matter. Journal of the JIME, 42 (2): 122-128.

Barrie, B. (2001). Analytical methods used in the production and fuel quality assessment of biodiesel. Trans. ASAE 44 (2), 193-200.

Barrie, B., (2001). "Fiscal Instruments for Air Pollution Abatement in Road Transport," Journal of Transport Economics and Policy, Volume XXIX, No.1, January, pp.33-51.

Barrie, B. (2001). "Legionella". Chapter 48 in Indoor air Quality Handbook by Spengler et al., McGraw-Hill ISBN 0-07-445549-4, 2001.

Centre for Sustainable Transportation (C.S.T), (2004). "Air Quality in Inter City Buses: Preliminary Report, December 17, 2004 (Draft)". Draft forwarded in private correspondence to Jay Kassirer of the study team. (www.cstctd.org). 
European Environment Agency (E.E.A) (2005). State of the Environment: Air quality 1990-2030, ETC/ACC Technical paper 2005/1.

Giannouli, M., Samaras, Z., Keller, M., de Haan, P., Kalivoda, M., Sorenson, S. and Georgakaki, A. (2006). Development of a Database System for the Calculation of Indicators of Environmental Pressure Caused by Transport, Science of the Total Environment, Vol. 357/1-3, pp. 247-270.

Hertel, O., Christensen, J.H., Runge, E.H., Asman, W.A.H., Berkowicz, R. and
Hovmand, Development and Testing, (1995). of a new Variable Scale Air Pollution Model ACDEP, Atmospheric Environment, 29, 20, 1267-1290,

Paul, G. Höglund. Estimation of Air Qality Improvement at Road and Street Intersections, (1995). Proceedings of the 10th World Clean Air Congress, Espo, Finland, -05- 28--06-02. Finnish Air Pollution Prevention Society. Volume 3, Impacts and Management, Session D2, paper 509.

يهدف البحث إلى در اسة و حساب تركيز الملوثات (الدقائق , بغداد نتيجة لإنتاج الطاقة الكهربائية من المحطات الكهربائية و المولدات الكيات الصغيرة. منظومات الكات إنتاج الطاقة

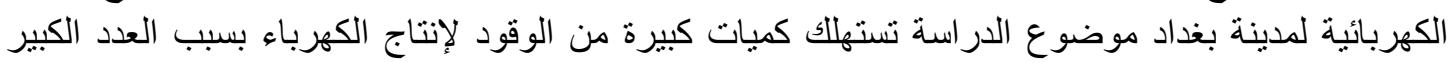

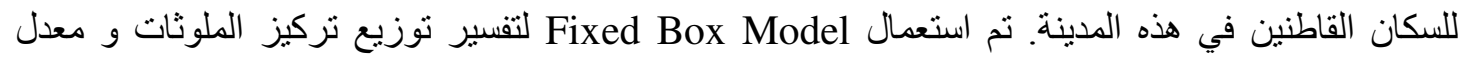

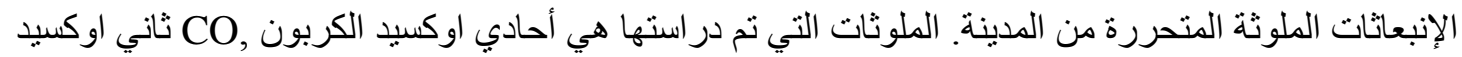

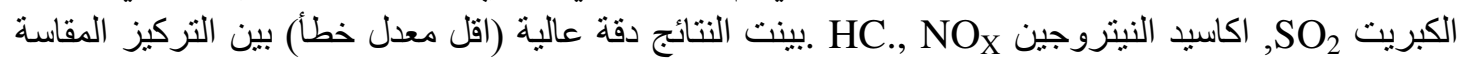
بجهاز القياس المحمول و التركيز المحسوبة باستخدام ال Fixed box model لجميع الملوثات .إن نسبة الخطأ

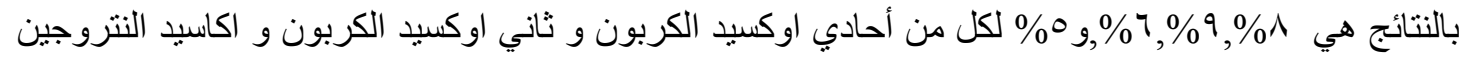

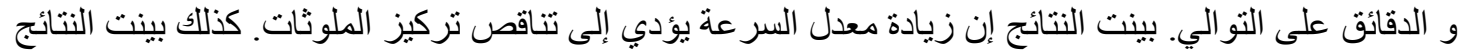

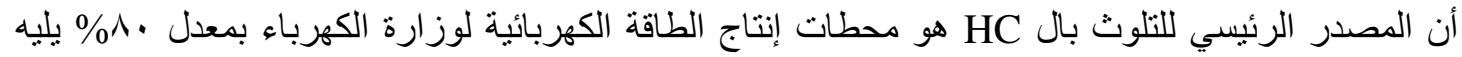
محطات الصغيرة المخصصة للطو ارئ بالدو ائر و المناطق و يليها مولدات الطو ارئ الصغيرة الطئ. 